\title{
GITA BĒRZIN,A
}

Latvijas Universitāte, Latvija

\section{AIZGUVUMU SEMANTIKA: GRIEĶISMI ROMIEŠU NACIONĀLĀ EPOSA VALODĀ}

\section{İss kopsavilkums}

Senās Romas kultūrā saskatāmas daudzas un dažādas ietekmes no senajiem grieḳiem, un nozīmīga ir arī grieḳu valodas ietekme uz latīṇu valodas (jo ìpaši klasiskā perioda) attīstības procesiem.

Rakstā uzmanība pievērsta grieḳu valodas aizguvumiem vienā no klasiskās latīṇu valodas izcilākajiem tekstiem - Vergilija Eneidā. Tā analīze rāda, ka aizguvumi no grieḳu valodas, t. sk. kalki, Vergilija eposa valodā izmantoti mērḳtiecīgi ar daudzveidīgu semantiku.

Sekojot sengrieḳu episkās dzejas tradīcijas aizsācēja Homēra paraugam, aizguvumi, pirmkārt, plaši kalpo grieķu pasaules atslēgelementu - raksturīgu kultūras reāliju - identificēšanai. Valodu mijiedarbe atklāj kultūrvērtību mijiedarbi. Otrkārt, grieḳismu lietojums daudzpusīgi noder autora literārā statusa apliecinājumam un episkās valodas tradīcijas turpināšanai un aktualizēšanai. Tie niansē un mākslinieciski bagātina konkrētā eposa izteiksmi un būtiski paplašina latīṇu valodas līdzekḷu un paṇēmienu klāstu. Citviet turpretim aizguvumi no grieḳu valodas izmantoti specifiskāk, noteiktā konsituācijā spilgti kalpojot autora individuāliem poētiskiem mērḳiem (piem., citādā izcelšanai, svešā un nesaprotamā iezīmēšanai u. tml.).

Atslēgvārdi: aizguvums, grieḳisms, klasiskā latīṇu valoda, Vergilija Eneida.

Senās Romas kultūrā saskatāmas daudzas un dažādas ietekmes no senajiem grieķiem. Daudzus gadu simtus romieši dzīvo līdzās uzplaukstošai sengrieķu kultūrai. Un, kamēr Roma vēl tikai top, grieksi ir jau radījuši izcilu literatūru, likuši pamatus Rietumu filozofijai un zinātnei, guvuši ievērojamus panākumus mākslā un arhitektūrā. Romai augot un pamazām attīstoties tās kultūrai un intelektuālajai domai, un jo īpaši pēc Grieķijas pakḷaušanas 2. gs. p. m. ē., tā neizbēgami saskaras ar grieķu kultūru un grieḳu valodu un aizgūst sev svarīgo dažādās jomās. Nozīmīga ir arī grieḳu valodas ietekme uz latīnu valodas attīstības procesiem. 
Katrai no abām klasiskajām valodām vērojamas savas raksturīgās izpausmes un īpatnības, un vairāku gadu simtu līdzāspastāvēšanas rezultātā noteiktos laikposmos arī romieši atstājuši savas pēdas grieķu valodā, tomēr grieḳu valodas aizguvumi latīnu valodā ir daudz ievērojamāki. Turklāt daḷa no aizgūtā valodas materiāla tieši ar latīṇu valodas starpniecību tālāk nonāk dažādās Eiropas valodās.

Aizgūšana kā valodu saskares ietekmēts process, kurā vienas valodas vienība tiek pārṇemta un pakāpeniski iekḷaujas citas valodas struktūrā, pakḷaujoties šìs citas valodas izrunas un rakstības noteikumiem un gramatikas likumiem (VPSV 2007, 20), ir kompleksa parādība. Un arī latīnu valodā aizgūšanas prakse ir daudzveidīga. Dažādos laikos dažādu faktoru ietekmē tā bijusi atškirīga - atšḳīušies aizguvumu ienākšanas mērḳi, jomas, aizgūtās valodas vienības, dominējošie aizgūšanas paṇēmieni un veidi, kā arī aizgūšanas intensitāte.

Visā daudzpusībā šo parādību vienā rakstā aplūkot nav iespējams, tāpēc šoreiz par grieḳu valodas aizguvumiem klasiskās latīṇu valodas vienā no izcilākajiem tekstiem, kas nozīmīgi ietekmējis arī Rietumeiropas kultūru, - Vergilija Eneidā. Šis teksts sava apjoma dēḷ sniedz pietiekami daudzveidīgas liecības plašāku secinājumu izdarīšanai un ar izgaismoto valodu materiālu var atklāt vērtīgus faktus par šo valodā kopumā tik svarīgo parādību arī citu valodu pētniekiem.

Grieķu valodas paraugi būtiski ietekmē vispār klasiskās latīnuu valodas veidošanos. Šis latīnu valodas normētais variants, kas kalpo par ideālu gadsimtiem ilgi (t. sk. kā pareiza un tīra valoda kḷūst par paraugu modernām literārajām valodām) un arī mūsdienās fiksēts vārdnīcās un gramatikās, attīstās laikā no apmēram 100. g. p. m. ē. līdz 150. g. m. ē. un izkristalizējas šì perioda labākajos - tādu autoru kā Cicerons, Cēzars, Vergilijs, Horācijs u. c. - literārajos tekstos.

Klasiskās latīnu valodas pamats ir romiešu dialekta rakstītā forma (t. s. sermo urbanus), un tā lielā mērā attīstās, grieķu valodas elementiem un paraugiem jau kopš apm. 240. g. p. m. è. papildinot tos latīnu valodas variantus, kas līdzās tautas neizglītotā vairuma runātajai valodai bija izkopti dažādiem sociokultūras mērḳiem (piem., likumu un rituālo tekstu, publisko oratoru runu, senāta un pontifikālo pierakstu valoda) (Coleman 2012, 796).

Mainoties vēsturiskajiem, politiskajiem, sociālajiem un kultūrvides apstākḷiem, mainās arī romiešu izpratne dažādos, tajā skaitā valodas, jautājumos un latīṇu valodas lietošana. 
Augstāko kārtu romieši izglītojas pie grieķu oratoriem, filozofiem un gramatiķiem, un grieķu valoda kḷūst par viṇu kultūras valodu. Ikviens izglìtots romietis var lasīt un runāt grieḳu valodā. Tas vedina romiešus arvien vairāk saskatīt un novērtēt grieḳu valodas īpašās kvalitātes - tai raksturīgos skaidras un precīzas izteiksmes principus un likumības (t. sk. gan attiecībā uz precīzām un diferencētām vārdu nozīmēm, gan gramatisko variāciju izslēgšanu, gan daḷeju morfologijas regularizēšanu) un jo īpaši ievērojamos leksiskos resursus (tanto est sermo Graecus Latino iucundior [..] Quint. Inst. 12.10.33). Tas plaši un daudzveidīgi ietekmē romiešu pašu valodas lietojumu un attīstību, sevišķi tās augstākajos variantos (plašāk skat. Coleman 1977; Clackson, Horrocks 2007, 184-198; Clackson 2011, 236-256).

Līdz ar dažādu jomu, tostarp arī tehnisko žanru, attīstību tiek izkopta latīṇu valodas lietošana specifiskiem mērķiem - gan tehnisku, gan filozofisku, gan arī māksliniecisku tēmu izklāstam. Grieķu valodas ietekmē latīnu valodā attīstās vairāk vai mazāk pien,emtas stabilas iezīmes, kas raksturīgas dažādiem žanriem, atšķirīgiem stiliem un noteiktam lietojuma kontekstam (plašāk skat. Palmer 1954, 95-147; Clackson, Horrocks 2007, 215-227). Valodā raisās virkne sintaktisko un stilistisko pārmaiṇu un noris bagātīga latīṇu vārdu krājuma papildināšana (plaša leksikas aizgūšana, jaundarināšana un pielāgošana). Turklāt grieḳu valodas paraugs palīdz nostiprināt izpratni par lingvistiskās normas nepieciešamību, un tas l̦auj sekot procesiem valodā un savā ziṇā normēt valodu visos tās līmeṇos - gan leksikā un vārddarināšanas jautājumos, gan morfologijā un sintaksē.

Tā klasiskā latīṇu valoda šai posmā būtiski attīstās pēc grieķu valodas parauga, un liela nozīme un vieta te ir arī aizguvumiem. Aizgūtas tiek dažādas valodas vienības un paṇēmieni, tomēr visspilgtāk un ilglaicīgāk grieḳu valodas ietekme izpaužas leksikā (skat. Coleman 1977, 105-106), daḷai aizgūtā leksiskā materiāla caur latịnu valodu tālāk nonākot dažādās Eiropas valodās (piem., liela daḷa mūsdienu Eiropas valodu dažādu jomu terminoloǵijas ir atvasināta tieši vai netieši no latīṇu valodas vārdiem, kuru izcelsme saistās ar šo laiku).

Aizguvumu klasiskajā latīn,u valodā ir daudz, un tieši grieḳu valoda ir ḷoti bagātīgs avots šai ziṇā. Kā jau 19. gs. beigās savā darbā par aizguvumiem latīṇu valodā norādījis Edvards Vartons (Edward Ross Wharton, 1844-1896), grieķu valodā ir apmēram 2,5\% aizgūtu vārdu, bet latīṇu valodā ap 14\%, proti, pēc viṇa datiem, sengrieķu valodā līdz 300. g. p. m. è. 
ir 41100 vārdu, no kuriem varbūt 1000 ir aizgūti, bet klasiskajā latīṇu valodā no 26300 vārdiem līdz m. è. 117. gadam ap 3500 vārdu ir aizgūti no grieḳu valodas un ap 300 no citām valodām (neietverot to skaitā îpašvārdus) (Wharton 1888, 1).

Romieši, lasot un tulkojot dažādu jomu griek̦u tekstus (it sevišḳi tehniskos, zinātniskos tekstus), kā arī paši rakstot par jaunām tēmām, sastopas ar jēdzieniem, kuriem latīṇu valodā vēl nav apzīmējumu. Viṇi ir spiesti pielāgot latīṇu valodas vārdu krājumu un kā divu valodu pratēji izmanto vairākas iespējas un dažādus veidus, lai rastu atbilstīgu apzìmējumu.

1. Romieši tieši aizgūst grieķu vārdu (aizguvums). Tādi aizguvumi ir,

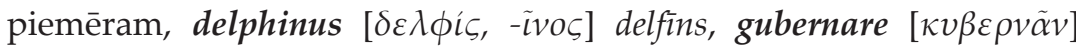

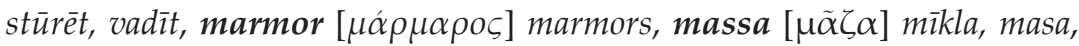

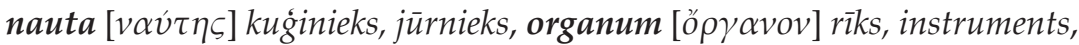
podium [

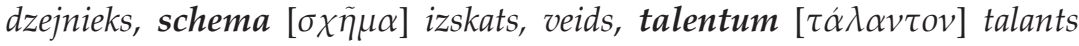
(nauda); ar intelektuālās domas un dažādu zinātṇu jomu attīstību saistīti aizguvumi, piemēram, grammaticus [ $\gamma \rho \alpha \mu \mu \alpha \tau \iota \kappa o ́ c]$ gramatikis,

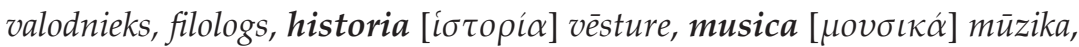

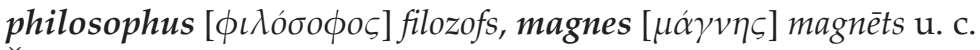

Šie aizguvumi iekḷaujas latīṇu valodas vārdu krājumā un lielākoties tiek asimilēti atbilstošajās deklinācijās: a-celmi 1. deklinācijā, o-celmi 2. deklinācijā, pārējie - 3. deklinācijā.

2. Tiek paplašināta esoša latīṇu valodas vārda nozīme, iekḷaujot attiecīgā grieķu vārda nozīmi (semantiskais kalks). Piemēram,

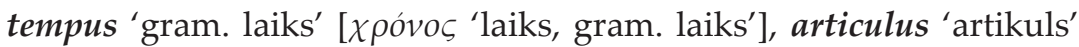

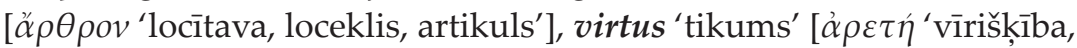
krietnums, tikums'], musculus 'muskulis' [dem. no mus [ $\mu \tilde{v} \varsigma]$ 'pele, anat. muskulis'] u. c.

3. Morfēmu pa morfēmai tiek tulkots grieķu vārds, lai radītu jaunu latīṇu vārdu (morfologiskais kalks). Proti, no pašas latīṇu valodas elementiem tiek darināti jauni salikteṇi un atvasinājumi, kopējot grieḳu leksēmu morfologisko struktūru. Piemēram, essentia [esse] 'būtība, esība', tulkojot grieķu ov̉oía, Cicerona darinātais qualitas [quālis] 'kvalitāte',

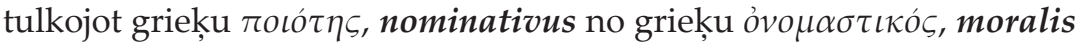
atbilstīgi grieksu $\ddot{\theta} \theta \iota \kappa o ́ \varsigma$ u. c.

4. Tiek izmantota aprakstoša izteiksme (Coleman 1989, 77-8; Powell 1995, 288; Anttila 1989, 140). 
İpaša aizgūšanas prakse attīstās literāros tekstos, kur tas tiek darīts ne tikai inopia, bet arī imitatio un mākslinieciskai valodai svarīgā ornatus dēl (skat. Quint. Inst. 1.5.58; 8.6.32). Līdzīgi kā citās valodās (tostarp arī latviešu) būtiska nozīme latīṇu valodas vārdu krājuma attīstǐšanā un izkopšanā ir tieši izcilo autoru valodas lietojumam. Kā norāda Kvintiliāns savā darbā Institutio Oratoria, principāta laikā pareizas valodas (Latinitas) paraugu oratorprozā sniedz Cicerons un Cēzars, vēsturiskajā prozā Lìvijs un Sallustijs, lirikā Horācijs, bet episkajā dzejā Vergilijs (Quint. Inst. 10.).

Jāatceras, ka romiešu latīṇvalodīgā literatūra 3. gs. p. m. è. vispār sākas ar grieķu literāro tekstu tulkojumiem un būtiskā mērā veidojas, balstoties uz grieķu literatūras un līdz ar to arī grieķu valodas paraugiem.

Arī Eiropas kultūrtelpai svarīgā eposa žanra aizsākumi rodami sengrieḳu kultūrā, kur izveidojas žanra satura un formas konstantes, un sengrieḳu valodā attīstās arī izteiksmes kvalitātes, kas vairāk vai mazāk stabili tiek pārmantotas vispirms Romā, tad arī vēlākajā Eiropas episkajā tradīcijā. To spilgti atklāj romiešu nacionālā eposa - Vergilija Eneidas teksts, kas tapis romiešu zelta laikmetā (29.-19. g. p. m. ē.), lai episka vēstỉjuma formā cildinātu Romas varenību un vienlaikus sniegtu Augusta laikmeta kultūrai būtiskas ideologiiskās nostādnes.

Vergilijs, sekojot sengrieķu episkās dzejas tradīcijas aizsācēja Homēra paraugam, aizgūst ne tikai motīvus, ainas, kompozicionālā strukturējuma principus, lai tos atbilstīgi saviem mērḳiem pārapjēgtu, padziḷinātu un niansēti izmantotu, bet arī valodas un mākslinieciskās izteiksmes līdzekḷu lietojumu (plašāk skat., piem., Knauer 1990, 390-412).

Vergilija eposs vēsta par Trojas varoni Eneju (Aineju), kuram ar dievu atbalstu lemts pamest degošo Troju, lai dotos jaunas dzimtenes meklējumos, kur viṇa pēcnācējiem vēlāk dibināt dižo Romu. Eposa sižeta risinājums jau pašos pamatos paredz būtisku grieķiskās un romiskās pasaules saistību/mijiedarbi, un likumsakarīgi arī eposa valodā vērojams plašs leksiskais materiāls, virkne aizguvumu no grieḳu valodas, kas atspoguḷo grieķu pasaules vietu un personu vārdus, kā arī kultūras reālijas, piemēram:

1) poētiskais Trojas nosaukums Ilium vai - grieķiskā formā - Ilion

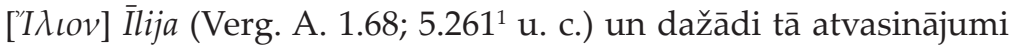
Ilius, Iliacus - İlijas- (Ilius tellus 9. 285; Iliacas oras 2.117; penates 3.603; classis 5.6-7 u. c.); kā arī citi geogrāfiski nosaukumi un to

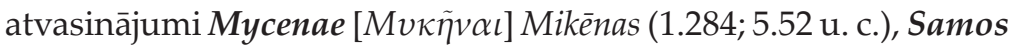




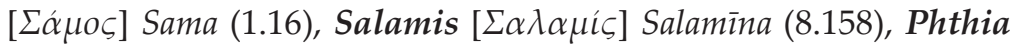

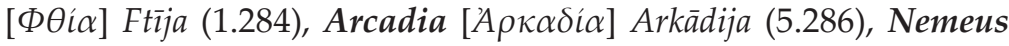

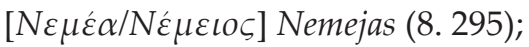

2) grieķu un trojiešu apzīmējumi Danaus [ $\Delta \alpha v \alpha o ́ c]$ danajs, grieķis

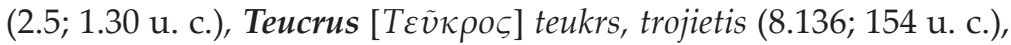

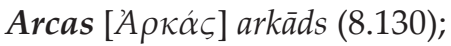

3) dievu (citu mītisku personāžu) un varoṇu vārdi Apollo [Aтód $\lambda \omega \nu$ ]

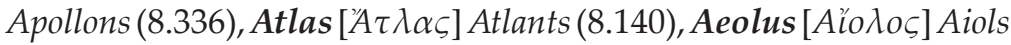

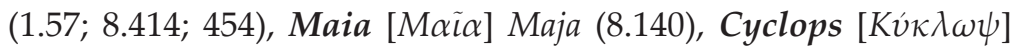
Kiklops (8.440), Dardanus [ $\Delta \alpha \dot{\alpha} \delta \alpha v o \varsigma]$ Dardans (8.134), Priamus

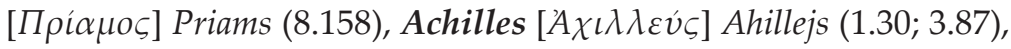

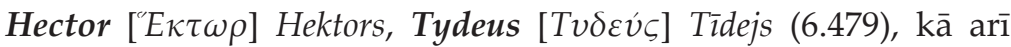
atvasinājumi no tiem (visbiežāk dažādi īpašības vārdi, piem., Aeolius, a, um Aiola);

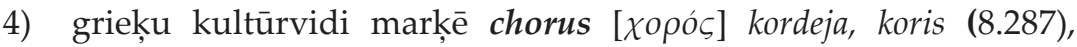

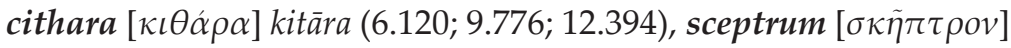

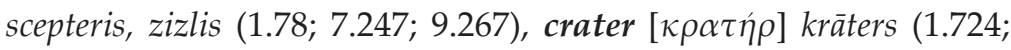
$3.525 ; 9.266)$, chlamys $[\chi \lambda \alpha \mu v ́ \varsigma]$ hlamīda, pharetra $[\phi \alpha \rho \varepsilon \dot{\tau} \rho \alpha]$ bultu

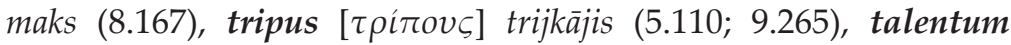

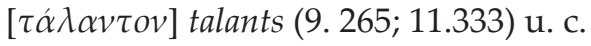

Šie aizguvumi plaši kalpo grieḳu pasaules atslēgelementu - raksturīgu vides un kultūras reāliju - identificēšanai, līdzīgi kā tas būtu ikvienā gadījumā, kad vienas kultūras reāliju apzīmējumi izmantoti citas valodas tekstā. Valodu mijiedarbe atklāj kultūrvērtību mijiedarbi.

Tomēr grieķismu lietojumam Vergilija tekstā ir vēl daudz plašāka nozīme. N̦emot vērā episkās dzejas aizsākumus un tradīcijas attīstību, aizguvumi no grieḳu valodas Vergilijam daudzpusīgi noder arī viṇa literārā/poētiskā statusa apliecinājumam un episkās valodas tradīcijas turpināšanai un aktualizēšanai.

Jau iepriekš minētās leksēmas - poētiskais Trojas nosaukums Ilium (Ilion), Ahilleja dzimtene Ftīja (Phthia), grieķu karaspēka karavadoṇa Agamemnona Mikēnas (Mycenae) vai pašu seno grieķu un trojiešu varoṇu vārdi Achilles, Hector u. c. - precīzi atgādina par Homēra eposiem. Tie nav kaut kādi varoṇi, un tās nav tikai kādas nejauši izvēlētas Grieḳijas vietas, tās ir vietas, kas saistās ar Homēra varoṇiem un viṇa episko tradīciju, un romiešu auditorija to apzinās. 
Līdz ar grieḳu mītisko un episko varoṇu identificēšanu episkas valodas tradīciju Vergilija latīṇu tekstā spilgti aktualizē arī grieḳu patronīmu lietojums. Sastopamas vairākas formas, piemēram:

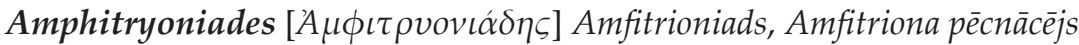
(Hērakls) $(8.103 ; 214)$;

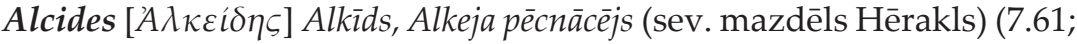
8.202; 249);

Atrides(-a) [Ā $\rho \varepsilon i \delta \eta\rceil \zeta]$ Atrīds, Atreja pēcnācējs (Agamemnons vai Menelājs) (8.130);

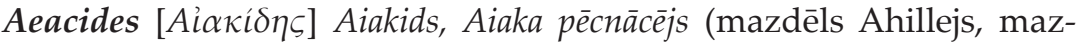
mazdēls Pirrs) (Ahillejs 1.99), (Pirrs 3.296);

Laomedontiades [ $\Lambda \alpha o \mu \varepsilon \delta o v \tau \iota \alpha ́ \delta \eta \varsigma]$ Lāomedontiads, Lāomedonta pēcnācējs (Priams) (8.158; 162);

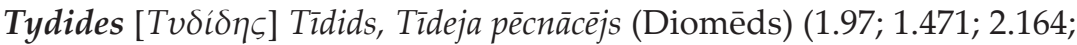
2.197) u. c.

Varoṇa apzīmējums ar leksēmu, kas veidota no tēva, vectēva vai vēl senāka senča vārda, tai pievienojot attiecīgu izskaṇu, ir ierasts sengrieķu valodas paṇēmiens kopš seniem laikiem, kā to apliecina jau pirmās mums pieejamās šīs valodas liecības (Palmer 1980, 34; Smyth 1984, 233-234). Vēlākā laikā šis tips zaudē savu aktualitāti/produktivitāti un jau klasiskajā periodā vairs netiek lietots vēsturisko personu pēcnācēju apzīmēšanai, taču paliek kā senākā valodas slāṇa raksturīgs elements un tiek izmantots senatnīgas, cildenas un poētiskas izteiksmes veidošanai.

Patronīmi ar -ides/-iades plaši vērojami Homēra tekstos, raksturojot grieķu un trojiešu varoṇus, un šo tradīciju pārņem un izmanto nu jau citas - latīṇu - valodas tekstā Vergilijs.

Turklāt romiešu eposā nereti lietotas arī grieḳu valodas gramatiskās formas. Lai gan, kā iepriekš minēts, aizguvumi latīnu valodā iekḷaujas un lielākoties tiek asimilēti atbilstošajās deklinācijās, vienai daḷai grieḳismu tiek saglabāta grieḳu valodas deklinēšana. Tas īpaši sakāms par īpašvārdiem (t. sk. patronīmiem). Vergilija eposa tekstā plaši sastopami gan, piemēram, grieḳiski nominatīvi kā vienskaitlī, tā daudzskaitlī Aeneas (1.230; 544), Anchises (2.687), Phryges (1.468; 9.134), Cyclopes, gan akuzatīvi Aenean (1.260; 8.308), Anchisen (3.710; 6.670), Aioliden (6.164), Lāomedontiaden (8.158; 162), Sidona (1.619), Troas (1.30), Arcadas (10.397), gan arī vokatīvi Aenea (10.228), Anchise (3.475), Tydide (1.97) u. c. Dažkārt grieķiskās locījumu formas izmantotas arī sugas vārdiem, piemēram, heros $(1.196 ; 6.103)$, cratera $(3.525)$, crateras 
(1.724; 9.165) u. c. Šìs formas kalpo, lai distancētu eposa izteiksmi no ikdienai raksturīgās, poētiskotu Eneidas tekstu, kā arī lai atgādinātu par episkās valodas tradīciju.

Dzejas valoda tiecas izmantot no ikdienas valodas atšķirīgus izteiksmes līdzekḷus, un latīṇvalodīgajā dzejā viens no būtiskākajiem citādas/ neierastas izteiksmes avotiem gan tās pārstāvētās intelektuālās kultūras

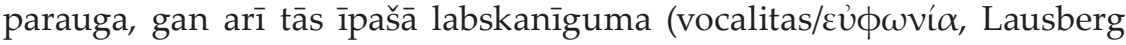
1998, 225, 246) dēḷ ir grieķu valoda un dažāda veida aizguvumi no tās. Kā norāda Kvintiliāns:

\section{[..] tanto est sermo Graecus Latino iucundior, ut nostri poetae, quotiens dulce} carmen esse voluerint, illorum id nominibus exornent. (Quint. Inst. 12.10.33)

Spilgtākie, protams, ir leksiskie aizguvumi.

Tā būtisks episkās valodas tradīcijas aktualizēšanai ir, piemēram, leksēmas heros ar nozīmi varonis lietojums. Tas ir aizguvums no grieķu

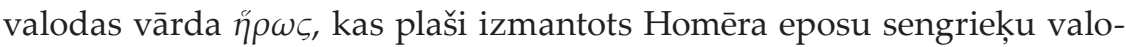
dā. Vergilijs varoṇa tiešo apzīmējumu neizmanto bieži, bet, kad to dara, lieto tikai šo no grieķu valodas aizgūto leksēmu, un tā tūlīt tekstā nes līdzi visu ar to saistīto kultūrkontekstu - atsauci uz Homēra eposu heroisko realitāti un to izcilajiem varoṇiem, ar ko nu sastatīti Vergilija varoṇi (dederat heros 1.196; magnanimi heroes 6.649; incipit Aeneas heros 6.103; Troius heros 6.451). Turklāt šì leksēma arī citu romiešu autoru tekstos lietota maz. Bez Vergilija lietojuma atsevišḳi gadījumi vērojami vēl Cicerona (heroum veteres casus imitari Cic. de Or. 2,47, 194), Ovidija (Ov. Tr. 5.5.3) un Horācija (Ajax heros Hor. S. 2, 3, 193; Hor. C. 1, 12, 1) tekstos, Ciceronam retumis lietojot heros arī pārnestā nozīmē izcilu vīru apzīmēšanai (Cic. Att. 1, 17, 9; Att. 14, 6, 1; Att. 4, 3, 5; Rep. 3, 8).

Kā spilgts leksiskais aizguvums ar poētisku slodzi minama arī leksēma Hesperia, kas izmantota kā poētisks Itālijas apzīmējums. Hesperia, ae, f (sc. terra) Rietumu zeme, Hesperija, substantīvs veidots no adjektīva Hesperius, a, um (vakara, kas novietots rietumos), kas atvasināts no Hesperus,

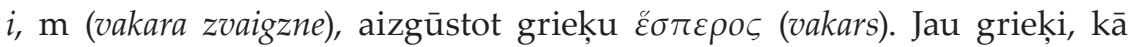
tas vērojams, piemēram, hellēnisma dzejnieka Rodas Apollonija eposā

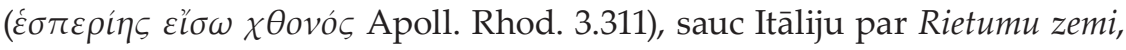
ṇemot vērā tās novietojumu uz rietumiem no Grieḳijas. Vergilijs to aizgūst un līdzās pamatā lietotajai leksēmai Italia vairākkārt īpaši nozīmīgos momentos, piemēram, Trojas penātiem Enejam (Ainejam) sapnī 
pareǵojot Itāliju kā lemto zemi (3.163), mērḳtiecīgi izmanto sava eposa tekstā: est locus, Hesperiam Grai cognomine dicunt (1.530; 3.163), Hesperiam magnam (1.569), terram Hesperiam venies (2.781), Hesperia in magna (7.4) u. c.

Vergilijs, izmantojot spilgtu, no grieḳu valodas aizgūtu poētismu, ne tikai niansē un mākslinieciski bagātina sava eposa valodu un noteiktos momentos atbilstoši konkrētiem poētiskiem mērķiem veido īpaši cildenu izteiksmi, bet arī vienlaikus (kas nav mazsvarīgi!) sasaista sevi ar zināmo episko, kultūras, literāro un lingvistisko tradīciju.

İpaša nozīme atšķirīgas/citādas mākslinieciskas izteiksmes veidošanā saistībā ar episko tradīciju ir arī saliktajiem epitetiem.

Sengrieķu valodā salikteņu darināšana ir ierasts paṇēmiens. Homēra eposu tekstā tas izmantots, veidojot saliktos epitetus kā spilgtus apzīmētājus, kas raksturo dievus, varoṇus, priekšmetus un dažādas parādības, un iedibinot to kā stabilu episkā stila iezīmi Eiropas literārajā kultūrā uz daudziem gadu simtiem. Šìs tradīcijas turpināšanā un sava literārā teksta kā izcila eposa kvalitāšu apliecināšanā būtiska nozīme ir Vergilija praksei, izmantojot saliktos epitetus Eneidā. Daḷa no tiem ir acīmredzami aizguvumi no grieķu valodas, t. sk. kalki.

Vergilija eposā sastopami omnipotens (visvarens, visspēcīgs) (pater omnipotens 1.60; fortuna 8.334), magnanimus (augstsirdīgs, cēls, drosmīgs) (magnanimum Aenean 1.260; par Aineju arī 5.17; 407; 9.204; magnanimum heroum 6.307; heroes 649; equorum 3.704 u. c.), omniparens (visa radītājs/a) (terrae omnipotentis 6.595), auricomus (ar zelta matiem, zeltmatu) (auricomos fetus 6.141), longaevus (loti vecs) (longaeva sacerdos 6.321; 628; 764), aequaevus (viena vecuma) (regem aequaevum 2.561), grandaevus (poēt. dižena vecuma) (grandaevus Aletes 1.121), primaevus (ḷoti jauns) (primaevo flore iuveni 7.162), malesuadus (ḷaunu iesakošs) (malesuada fames 6.276), aliger (spārnains, spārnots) (aligerum amorem 1.663), turriger (tornuus nesošs, torniem greznots) (turrigerae Antemnae 7.631; 10.253), aeripes (varkāju) (aeripedem cervam 6.802), cornipes (ragkāju, nagains) (cornipedum equorum 6.591), centumgeminus (simtkārtējs, simtrocis) (centumgeminus Briareus 6.287), septemgeminus (septinkārtējs, ar septin̄ām ietekām) (septemgemini Nili 6.800), horrisonus (drausmīgi skanošs) (horrisono cardine 6.573), mortifer (nāvi nesošs, nāvīgs) (mortiferum bellum 6.279), umbrifer (ēnu nesošs, ènains) (nemus umbriferum 6.473) u. c.

Piemēram, omnipotens veidots no īpašības vārda omnis (viss) un tagadnes participa potens (varošs, no verba posse) pēc grieḳu salikteņa $\tau \alpha \gamma \kappa \rho \alpha \tau \eta ் \varsigma$ parauga, kas darināts no grieḳu valodas īpašības vārda 


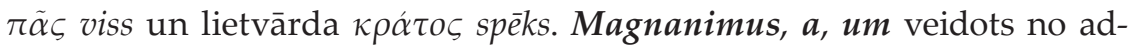
jektīva magnus (liels) un substantīva animus (dvēsele, gars), tulkojot no grieķu valodas Homēra $\mu \varepsilon \gamma \alpha \dot{\theta} \theta v \mu o \zeta$, kas darināts no $\mu \dot{\varepsilon} \gamma \alpha \varsigma$ liels un $\theta v \mu o ́ \varsigma$

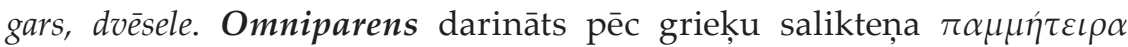

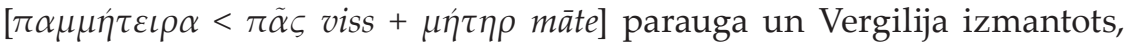
runājot par zemi, līdzīgi kā Homērs savā tekstā to izmanto, raksturojot

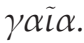

Savukārt auricomus, a, um, kas veidots no aurum (zelts) un coma

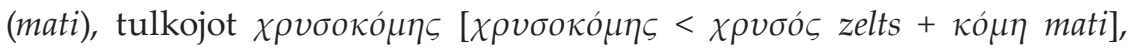
ir paša Vergilija darināts kā poētisks apzīmējums zelta zaram (aureum ramum), simboliskajai atslēgai uz mirušo valstību, kur Enejam (Ainejam) jādodas sastapt tēva ēnu un savām acìm redzēt nākamā Romas diženuma apliecinājumus.

Un līdzīgi pēc grieķu valodas parauga veidoti arī pārējie minētie epiteti. Tie kalpo gan varoṇu, gan vides reāliju, priekšmetu un parādību, gan abstraktu spēku izteiksmīgam raksturojumam. Daḷa vairākkārt lietoti jau pirms Vergilija citu autoru tekstos (piem., omnipotens, magnanimus), citi sastopami atsevišķos gadījumos, piemēram, Ennija agrīnajā eposā. Bet par daḷu šo salikteṇu (piem., auricomus, centumgeminus, longaevus, aeripes, cornipes) pirmās liecības sniedz tieši Vergilija teksts, un tie uzskatāmi par viņa apzināti veidotiem atbilstīgi iecerētam poētiskam iespaidam konkrētajā tekstvietā.

Saliktie epiteti, kas darināti pēc grieḳu valodas parauga un dạ̣ā gadījumu pat tieši tulkoti, gan attīsta episkās izteiksmes tradīciju latīṇu valodā, gan paplašina, bagātina latīṇu valodas leksiku ar jaunām, niansētām, dažkārt pavisam kompleksām nozīmēm.

Taču ir gadijumi, kad aizguvumi no grieķu valodas Vergilija Eneidā izmantoti specifiskāk. Tie nav saistāmi ar episkās valodas tradīciju, bet izteikti kalpo autora individuāliem poētiskiem mērḳiem.

Spilgts piemērs vērojams eposa 4. dziedājumā Kartāgas valdnieces Dīdonas raksturojumā, kad tā uzzina par varoṇa Eneja (Aineja) došanos prom pēc dievu pavēles, atsakoties no valdnieces iecerētajām nākotnes saistībām/laulībām.

Saevit inops animi, totamque incensa per urbem

bacchatur, qualis commotis excita sacris

Thyias, ubi audito stimulant trieterica Baccho

orgia, nocturnusque vocat clamore Cithaeron. (4.300-304) 
Nevaldot sevi, tā plosās un klaiņo pa pilsētu visu,

$\bar{I}$ gnumā kaistot, kā tijāda straujā, kas ierauga nesam

Upuru traukus, dzird gaviles Bakham, kad trijgadu svētki

Skubina viņu un Kitairons naktī sauc [orợiju dejās]. (A. Ģiezena tulkojums)

Trijās rindās izmantotas 6 leksēmas, kas aizgūtas no grieķu valodas:

1) darbības vārds bacchārī, atvasināts no vīna dieva Bakha vārda

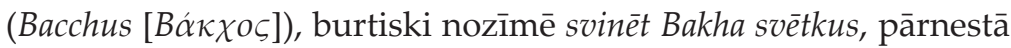
nozīmē, kā to arī šeit lietojis Vergilijs, tas nozīmē skraidīt/klīst apkārt eksaltētā procesijā, mežonīgi plosoties (A. Ģiezena literārajā tulkojumā klaiņo). Latīnu valodā leksēma izmantota dzejā vai atsevišķos hiperbolizētas izteiksmes gadījumos prozā (piem., Plaut. Am. 2.2.71; Cat. 64.61; 64.255; Cic. Cat.1.26);

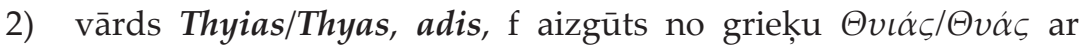
nozīmi tijäda, proti, iedvesmota, pārnemta sieviete, bakhante. Saistīts ar $\tau \dot{\alpha} \Theta v i ̃ \alpha$ - Bakha svētkiem Elidā. Latīṇu dzejā leksēma vienskaitḷa formā izmantota tikai trīs reizes - pa vienai Vergilija, Horācija (Hor. C. 3.15.10) un Stacija (Stat. Th. 5.92) tekstos, vēl daži gadījumi daudzskaitḷa formā (Cat. 64.392; Hor. C. 2.19.9; Ov. F. 6.514);

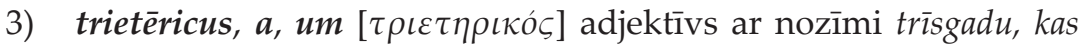
notiek ik trešo gadu, tiek lietots tieši, runājot par Bakha svētkiem. Bez Vergilija atsevišḳi gadijumi sastopami vēl tikai Ovidijam (Ov. M. 6.587; Am. 593) un Stacijam (Stat. Th. 2.661; Achill. 1.595);

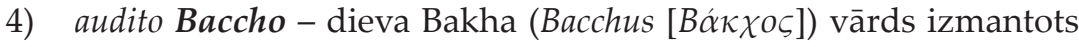
metonīmiski, apzīmējot orǵijās plaši izmantoto izsaucienu Io Bacche!;

5) Orgia, orum ['O $\rho \gamma \iota \alpha]$ ar nozìmi nakts svētki par godu Bakham, oróijas

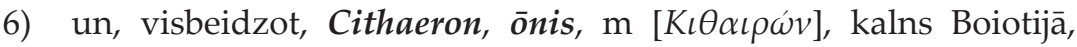
Griek,ijā, svēts Bakham, kur ik pa trim gadiem notika bakhanāliju svinēšana. Leksēma vēl vairākkārt lietota Vergilija eposa tekstā (piem., 7.641; 10.163).

Vergilijs valdnieces rīcību tieši apzīmē ar nozīmes ziṇā izteiksmīgo verbu bacchārī, tālāk sniedzot izvērstu salīdzinājumu ar tijādas, citiem vārdiem, bakhantes, kaismīgo, mežonīgo izturēšanos ar spilgtām norādēm iezīmētos Bakha svētkos. Ar grieķismu blīvējumu autors rada spilgtu ainu par Dīdonas nekontrolētām emocijām un nevaldāmu to izpausmi. Tā ir - vismaz pēc Augusta laikmeta ideoloǵijas, kas tiecas 
izcelt un cildināt noteiktas morālās, ètiskās vērtības, stingrus tikumus romietim nepieṇemama un atbilstīgi veiksmīgi atainota ne ar latīṇu cilmes valodu.

Līdzīgs aizguvumu no grieḳu valodas pastiprināts izmantojums vērojams arī citā ainā - 7. dziedājumā, kad, Enejam (Ainejam) nonākot likteṇa lemtajā zemē, viṇam naidīgā Jūnona, lai izjauktu tā laulības ar Latīna meitu Lavīniju, sūta fūriju Alekto sakūdìt Latīna sievu Amātu. Jau Jūnonas runā lietota virkne grieķismu, bet to koncentrācija un semantika īpaši iezīmējas, Alekto iemetot indīgu čūsku Amātai azotē un sekojošo Latīna sievas izpausmju raksturojumā.

\section{Exin Gorgoneis Allecto infecta venenis}

principio Latium et Laurentis tecta tyranni

celsa petit tacitumque obsedit limen Amatae, quam super adventu Teucrum Turnique hymenaeis

femineae ardentem curaeque iraeque coquebant.

\section{[..] fit tortile collo}

aurum ingens coluber, fit longae taenia vittae innectitque comas, et membris lubricus errat.

Quin etiam in silvas, simulato numine Bacchi, maius adorta nefas maioremque orsa furorem evolat et natam frondosis montibus abdit, quo thalamum eripiat Teucris taedasque moretur, Euhoe Bacche, fremens, solum te virgine dignum vociferans, etenim mollis tibi sumere thyrsos, te lustrare choro, sacrum tibi pascere crinem. (7.341-345, 349-351, 385-391)

Alekto, pilna ar Gorgonas indēm, no turienes tūdal Dodas uz Latijas pusi pie Laurentas valdnieka nama Augstceltām mītnēm un sēstas pie Amātas mierīgā sliekšņna; Trojiešu ierašanās un gaidāmās kāzas ar Turnu Nesa tās satrauktai sirdij daudz sievišķ rūpju un raižu.

Lūk, riebīgā odze ap kaklu

Kḷust gan par savìtu zeltu, gan arī par matsaiti garu, Ievijas viņai jau matos un slìdot ap locekliliem glaužas. 
Un pat vēl vairāk, uz mežiem, kā bakhante sākdama trakot,

Stingdama lielākā vainā un lielāku niknumu rādot,

Dodas ar steigu un meiteni paslēpj tur ènainos kalnos,

Lai tik to atrautu teikriem un varētu aizkavēt kāzas.

"Euoi, tev, Bakh!" tā izsaucas skal̦i. "Tu vienīgais esi

Jaunavas cien̄̄gs! Lai maiglapu tirsu tev nèsā nu vina,

Dejo korī ap tevi un matus par godu tev audzē!" (A. Ģiezena tulkojums)

Citviet pat visai izvērstos eposa teksta posmos nav lietots neviens aizguvums no grieķu valodas, bet šeit to blīvejjums ir acīmredzams gan piesaucot grieķu mitoloǵiskās briesmones gorgonas (šeit ar adjek-

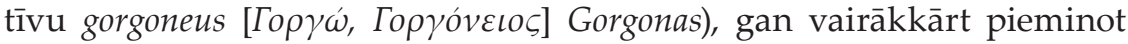

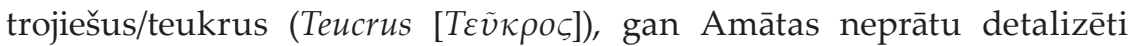
atainojot ar bakhanālijām raksturīgām reālijām un izpausmēm (euhoe

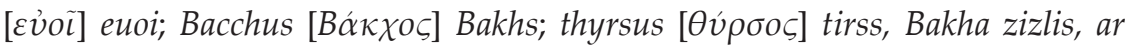

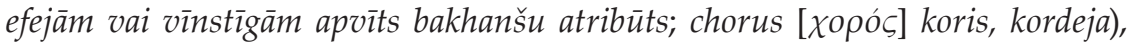

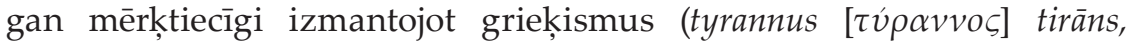

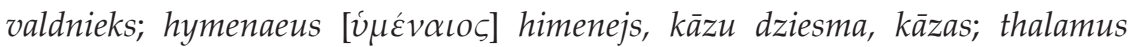

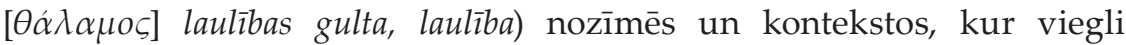
būtu lietot attiecīgus pašas latīnu valodas ekvivalentus. Un īpašs ir arī

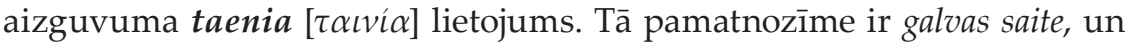
tā šḳiet identiska līdzās lietotam latịnu valodas vārdam vitta. Tomēr, kā norāda R. Lins (R. Lyne), šeit Vergilijs to drīzāk izmanto citā šī vārda nozīmē lentes tārps (Lyne 1989, 20-22). Konteksts kā nepatīkami iederīgu izgaismo šo griek̦isma otro nozīmi, kas terminologiski lietota gan griek̦u, gan latīnu valodas tekstos (Galen 14.755K; Cato Rust. 126 al.; Plin. Nat. 11.113 al. u. c.). Čūska kḷūst par Amātas zelta kakalarotu un baisi dzīvu galvassaiti matos.

Šajos divos gadijumos aizguvumi no grieķu valodas atklāj pavisam atšķirīgu semantiku, salīdzinot ar iepriekš minētajiem piemēriem. Grieḳismu lietojums šajās tekstvietās vairs nav saistīts ar episkās valodas tradīciju, bet spilgti kalpo autora individuālai mākslinieciskai iecerei - grieḳu kā tomēr citas, romietim nosacìti svešas valodas leksēmas izmantot citādā izcelšanai, svešā un nesaprotamā iezīmēšanai. Un līdzīgi piemēri saskatāmi Vergilija eposā arī vēl citviet.

Tādējādi aizguvumi no grieķu valodas, t. sk. kalki, Vergilija eposa valodā izmantoti ar daudzveidīgu semantiku.

Lai gan vairākkārt Vergilija eposa valodas pētījumos atzīmēts plašais sava laika/ikdienas valodas elementu un raksturiezīmju izmantojums 
Eneidas tekstā un to līdzsvarots apvienojums ar poētiskai valodai raksturīgām leksēmām un paṇēmieniem, kā arī salīdzinoši negaidīti mazais tādu latīṇu dzejas poētiskošanas līdzekḷu kā arhaismi un aizguvumi lietojums (Palmer 1954, 112-118; Wilkinson 1990, 418-419; Lyne 1989, 17), grieḳismu analīze eposa tekstā apliecina to mērḳtiecīgu izvēli un lietojumu.

Sekojot sengrieḳu episkās dzejas tradīcijas aizsācēja Homēra paraugam, aizguvumi, pirmkārt, plaši kalpo grieķu pasaules atslēgelementu raksturīgu kultūras reāliju - identificēšanai. Valodu mijiedarbe atklāj kultūrvērtību mijiedarbi.

Otrkārt, grieḳismu lietojums daudzpusīgi noder autora literārā statusa apliecinājumam un episkās valodas tradīcijas turpināšanai un aktualizēšanai. Tie niansē un mākslinieciski bagātina konkrētā eposa izteiksmi un būtiski paplašina latīnu valodas līdzekḷus un paṇēmienus.

Citviet turpretim aizguvumi no grieķu valodas kalpo autora individuāliem poētiskiem mērḳiem, noteiktā konsituācijā izgaismojot individuālas mākslinieciskas idejas.

\section{ATSAUCE}

1 Turpmāk, atsaucoties uz Vergilija Eneidas tekstvietām, norādīts tikai dziedājums un rinda, neatkārtojot atsauci uz autoru un viņa darbu.

\section{AVOTI}

1. Cato, Marcus Porcius. De agri cultura. G. Goetz (ed.). Lipsiae : Teubner, 1922.

2. Cicero's Letters to Atticus. Vol. 4. D. R. Shackleton Bailey (ed.). Cambridge : Cambridge University Press, 1968.

3. Cicero, M. Tullius. Librorum de Re Publica Sex. C. F. W. Mueller (ed.). Leipzig : Teubner, 1889.

4. Cicero, M. Tullius. Orationes. A. C. Clark (ed.). Oxonii : e Typographeo Clarendoniano, 1908.

5. Galenus, Claudius. Opera omnia. D. C. G. Kuhl (ed.). Lipsiae : Teubner, 1823.

6. Horace. Odes and Epodes. P. Shorey, G. J. Laing (eds.). Chicago : Benj. H. Sanborn \& Co, 1919.

7. Horace. The Works of Horace. C. Smart (ed.). Philadelphia : Joseph Whetham, 1836.

8. Ovidius, P. Naso. Amores, Epistulae, Medicamina faciei femineae, Ars amatoria, Remedia amoris. R. Ehwald (ed.). Lipsiae : Teubner, 1907.

9. Ovidius, P. Naso. Tristia. A. L. Wheeler (ed.). Cambridge, MA : Harvard University Press, 1939.

10. Plautus, T. Maccius. Plauti Comoediae. F. Leo (ed.). Berlin : Weidmann, 1895.

11. Plinius. Naturalis Historia. K. F. Th. Mayhoff (ed.). Lipsiae : Teubner, 1906. 
12. Quintilian. H. E. Butler (ed.). Cambridge. Cambridge, Mass : Harvard University Press; London : William Heinemann, Ltd. 1922.

13. Statius, P. Papinius. Statius. Vol. I-II. J. H. Mozley (ed.). London : William Heinemann; New York : G. P. Putnam's Sons, 1928.

14. Vergil. Bucolics, Aeneid, and Georgics. Greenough, J. B. (ed.). Boston : Ginn and Company, 1900

15. Vergilijs. Eneìda. A. Ģiezens (tulk.). Rīga : Liesma, 1970.

\section{LITERATŪRA}

1. A Greek-English Lexicon. H. G. Liddell, R. Scott, H. S. Jones, R. Mackenzie (eds.). Oxford : Oxford University Press, 1992 (1968).

2. Anttila, Raimo. Historical and comparative linguistics. $2^{\text {nd }}$ ed. Amsterdam : John Benjamins Publishing Company, 1989.

3. Clackson, James, Horrocks, Geoffrey. The Blackwell History of the Latin Language. Oxford : Blackwell Publishing, 2007.

4. Clacson, James. A Companion to the Latin Language. J. Clackson (ed.). Oxford : Blackwell Publishing Ltd, 2011, 236-256.

5. Coleman, Robert. Greek Influence on Latin Syntax. Transactions of the Philological Society, 1975, 1977, 101-156.

6. Coleman, Robert. Latin Language. Oxford Classical Dictionary (OCD). $4^{\text {th }}$ ed. S. Hornblower, A. Spawforth, E. Eidinow (eds.). Oxford, 2012, 796-798.

7. Coleman, Robert. The formation of specialized vocabularies in philosophy, grammar, and rhetoric: winners and losers. Cahiers de I'Institut de Linguistique de Louvain 15, 1989, 77-89.

8. Knauer, Georg Nicolaus. Vergil's Aeneid and Homer. Oxford Readings in Vergil's Aeneid. S. J. Harrison (ed.). Oxford : Oxford University Press, 1990, 390-412.

9. Latin Dictionary. Ch. T. Lewis (ed.). Oxford : Clarendon Press, 1991 (1879).

10. Latinu-latviešu vārdnīca. K. Veitmane, L. Čerfase, H. Novackis, A. Apīnis (sast.). Rīga : Latvijas Valsts izdevniecība, 1955.

11. Lausberg, Heinrich. Handbook of Literary Rhetoric: A Foundation for Literary Study. Leiden, Boston, Köln : Brill, 1998.

12. Lyne, R. O. A. M. Words and the Poet: Characteristic Techniques of Style in Vergil's Aeneid. Oxford : Clarendon Press, 1989.

13. Palmer, Leonard Robert. The Greek Language. London : Faber and Faber Ltd, 1980.

14. Palmer, Leonard Robert. The Latin Language. London : Faber and Faber Ltd, 1954.

15. Powell, Jonathan. Cicero's translation from Greek. Cicero the Philosopher. J. G. F. Powell (ed.). Oxford : Clarendon Press, 1995, 273-300.

16. Smyth, Herbert Weir. Greek Grammar. Harvard University Press, 1984.

17. Valodniecības pamatterminu skaidrojošā vārdnīca (VPSV). V. Skujiṇa (atb. red.). Rīga : LU Latviešu valodas institūts, 2007.

18. Wharton, Edward Ross. Loan-words in Latin. London, 1888.

19. Wilkinson, L. P. The Language of Virgil and Horace. Oxford Readings in Vergil's Aeneid. S. J. Harrison (ed.). Oxford : Oxford University Press, 1990, 413-428. 


\section{SEMANTICS OF BORROWINGS: GRECISMS IN THE LANGUAGE OF ROMAN NATIONAL EPIC}

\section{SUMMARY}

Ancient Roman culture abounds in many different influences from the ancient Greeks, and, as a matter of fact, the influence left by the Greek language on the processes of the development of the Latin language is extremely significant.

It is evident that the pattern of the Greek language has a particular influence on the formation of classical Latin. Under its influence, the Latin language becomes subjected to a series of syntactic and stylistic changes, and Latin word stock gradually becomes enriched with new words. In addition, certain more or less stable features characteristic to various genres, different styles and a definite usage context develop. The pattern of the Greek language also contributes to the understanding of necessity for a certain linguistic standard.

Borrowings play a great role in this respect. Various language units and devices are borrowed. However, lexical influence of the Greek language manifests itself most significantly in the course of time.

The Romans either directly borrow Greek words or subject the existing Latin words to semantic extension by including into it the meaning of a definite Greek word (semantic calques), as well as translate Greek words morpheme by morpheme in order to create new Latin words (morphological calques).

The development of a special borrowing practice can be observed in literary texts. where it is done not only for the sake of inopia, but also for the sake of imitatio and ornatus - so important for artistic expression.

The present paper focuses on Greek borrowings as found in one of the most outstanding texts representing classical Latin, i.e. Vergil's Aeneid. The analysis of the text shows that borrowings from the Greek language including calques in the language of Vergil's epic poem are used purposefully with diverse semantics.

Following the example of Homer as the beginner of ancient Greek epic tradition, borrowings in Roman epic first and foremost serve for the identification of certain key elements, characteristic culture features of the Greek world. 
Additionally, the use of Greek borrowings proves useful to the attestation of the author's literary status, as well as for continuation and actualization of the epic linguistic tradition.

Greek words have the potential of imparting various nuances and artistically enriching the expression of the epic under discussion, and they essentially extend the scope of the Latin language means and ways of expression.

However, it should be admitted that sometimes Greek borrowings are used for more specific intention - in a definite consituation, they serve the author's individual poetic purposes, e. g. in order to accentuate some kind of otherness or to mark the alien and the incomprehensible. 